Article

\title{
Impacts of Killing Process on the Nutrient Content, Product Stability and In Vitro Digestibility of Black Soldier Fly (Hermetia illucens) Larvae Meals
}

\author{
Yongkang Zhen ${ }^{1}$, Pipatpong Chundang ${ }^{2}{ }^{\oplus}$, Yu Zhang ${ }^{1}$, Mengzhi Wang ${ }^{1}$, \\ Wanwipa Vongsangnak ${ }^{3,4}$, Chantima Pruksakorn ${ }^{5}$ and Attawit Kovitvadhi ${ }^{2, * \mathbb{D}}$ \\ 1 College of Animal Science and Technology, Yangzhou University, Yangzhou 225009, China; \\ zyk1449691232@hotmail.com (Y.Z.); yuzhang@yzu.edu.cn (Y.Z.); mengzhiwangyz@126.com (M.W.) \\ 2 Department of Physiology, Faculty of Veterinary Medicine, Kasetsart University, Bangkok 10900, Thailand; \\ pichandang@gmail.com \\ 3 Department of Zoology, Faculty of Science, Kasetsart University, Bangkok 10900, Thailand; fsciwpv@ku.ac.th \\ 4 Omics Center for Agriculture, Bioresources, Food, and Health, Kasetsart University (OmiKU), \\ Bangkok 10900, Thailand \\ 5 Department of Microbiology and Immunology, Faculty of Veterinary Medicine, Kasetsart University, \\ Bangkok 10900, Thailand; fvetctm@ku.ac.th \\ * Correspondence: fvetawk@ku.ac.th; Tel.: +66-89-202-2677
}

Received: 14 August 2020; Accepted: 28 August 2020; Published: 2 September 2020

check for updates

Featured Application: Blanching is the best method with cost efficiency for killing black soldier fly larvae. Further study to discover the lowest boiling timing based on acceptable outcomes should be evaluated to reduce the processing cost. Moreover, the influences of killing methods on minerals, vitamins, amino acid and fatty acid profiles could be analyzed.

\begin{abstract}
The black soldier fly (BSF, Hermetia illucens) is considered a potential sustainable insect alternative source of protein for animal feed. The quality of a BSF meal is greatly influenced by the killing method and the purpose of this article is to compare the influences of different killing methods. BSFs at the 18-day-old prepupae stage were separated into six different killing methods with three replicates: 1 . blending, 2. freezing, 3. $\mathrm{CO}_{2}$ treatment, 4 . vacuum, 5. blanching and $6 . \mathrm{CO}_{2}$ plus blanching. After killing, BSF larvae meals were obtained by hot air oven drying and grinding. The chemical composition and in vitro digestibility calculated from sediments were not affected by the killing method, except that blending provided the worst BSF quality for all measured parameters $(p<0.05)$. The highest quality of BSF was obtained from the heat treatment procedures (blanching and the $\mathrm{CO}_{2}$ plus blanching methods), as they produced lower acidity after killing, total viable counts, browning reaction (enzymatic and non-enzymatic), darkness, moisture, fat acidity, protein and lipid oxidation during storage compared with other killing procedures $(p<0.05)$. Interestingly, the highest free amino acids in the supernatant after in vitro digestibility of BSF samples was observed with the $\mathrm{CO}_{2}$ plus blanching killing method $(p<0.05)$, whereas other parameters were similar to those obtained with blanching. The $\mathrm{CO}_{2}$ plus blanching method did not produce clearly different outcomes to blanching; therefore, the selection of one of these techniques over the other should depend on the regulations in each country.
\end{abstract}

Keywords: black soldier fly; killing methods; larvae meal; chemical compositions; in vitro digestibility 


\section{Introduction}

Nutrition is a major factor which influences the yield, health and profits of the animal production industry. Raw protein materials are the most expensive components in feed formulation when compared with other groups of nutrients. Therefore, protein sources of high quality with a reasonable cost should be an important consideration. Fishmeal and soybean meal have been used as general protein sources for the feed industry; however, these raw materials contain several disadvantages. Quality fluctuation and pathogen contamination are observed as disadvantages for fishmeal, whereas an imbalance in amino acids, low digestibility and anti-nutritional factors are presented in soybean meal. Moreover, these ingredients affect environmental deterioration [1,2]. In addition, the cost of soya and fishmeal are increasing $[1,2]$. Therefore, alternative protein raw materials should be sought as a solution to these problems.

In recent years, there has been increasing interest in insects as an alternative sustainable protein source for animals, especially in fish, poultry and swine [3]. Their suitable chemical composition, low-cost production procedures, high feed conversion efficiency and rapid, environmentally friendly productive cycle are advantages of insect production [1,2]. Moreover, most recent experimental studies have reported several benefits on growth performance, health and product quality using insects in feed formulation at the appropriate ratio [1,2]. However, the use of insects as an alternative protein source faces many challenges, including large-scale production with stability of product quality, price competitiveness with general protein sources and country-specific regulatory barriers [3]. Fortunately, consumers accept animal products produced from insect-fed animals; however, safety and quality control should be verified and observed by professional auditors along the production process [3]. In addition, the accumulation of heavy metals in black soldier fly (BSF) larvae is a consequence of feeding BSFs with contaminated substrates containing heavy metals, which is another important consideration point [4]. Insects are considered as a novel protein source; therefore, attention must be paid to the above challenges. In addition, the number of publications on the use of insects as a protein source for animals has only increased in the last decade [1,2]. Therefore, these challenges and barriers should be addressed in the near future.

Several insect species have been discovered and used with several benefits, whereas the black soldier fly (Hermetia illucens) has received the most attention as an alternative protein source for animals in tropical and temperate countries [5]. The large diversity of diets (organic waste: manure, food waste and industrial by-products), lower feed conversion ratio, absence of disease transmission to humans and inability to concentrate pesticides or mycotoxins from their diets in their body mass are some of the reasons driving interest in this insect species from researchers, insect farmers, animal producers and feed manufacturers [5]. Not only have waste management systems based on black soldier flies been established in several industries, but high-value products can also be obtained after the processing of products such as biodiesel, antimicrobial peptides and chitosan [5].

Consistent quality and safety are the most important considerations for black soldier fly farming and processing units. As we know, the diet is the most influential factor on the quality of black soldier fly (BSF) pupae meal [6]. However, the killing method is also a highly influential factor on BSF quality [1,7-9]. Heat treatment, freezing, asphyxiation and mechanical disruption are the general procedures to euthanize black soldier fly prepupae [8]. A fast killing method with heat treatment (blanching in boiling water for a short time) has been suggested and can decrease the amount of microbial contamination, conserve nutrient quality, prevent degeneration of the end product and provide a bright color which is acceptable to consumers, whereas slow killing methods without heat treatment (freezing, asphyxiation and blending) provide adverse consequences [7-9]. In contrast, Montevecchi et al. [10] reported that blending was the best procedure for preserving fat integrity. Freeze-drying or blending without any heat treatment were performed after killing procedures to obtain a sample for further laboratory analysis [7-10], which was different from the general processing procedure of baking killed black soldier fly prepupae in an oven until they reached less than $10 \%$ moisture, then grinding and storing them in a vacuum pack and/or freezing them at 
$-20^{\circ} \mathrm{C}$. The sensory response to pain is presented in insects; therefore, ethical aspects of welfare should also be considered [11]. Based on livestock slaughtering regulations, animals must be unconscious before the killing procedure. For this reason, $\mathrm{CO}_{2}$ was provided for BSFs before boiling to make them unconscious before the killing procedure. Therefore, the effects of different killing procedures (heating, freezing, asphyxiation or $\mathrm{CO}_{2}$ plus blanching methods) on the quality of oven-dried BSFs were evaluated in the current study.

\section{Materials and Methods}

\subsection{Animals, Killing Procedures and Processing}

BSF prepupae at 18 days of age were obtained from a commercial black soldier fly farm (Orgafeed Co. Ltd., Bangkok, Thailand), to which a fattening broiler chicken diet and palm kernel meal were fed as the main diets. After an adaptive period in a temperature-controlled room $\left(27^{\circ} \mathrm{C}\right)$ for $4 \mathrm{~h}$, black soldier flies were separated randomly into six groups with three replicates $(1 \mathrm{~kg}$ of black soldier fly prepupae in fresh matter per replicate). The killing methods were adapted from other research studies [7-10]. Six different killing procedures were performed as follows: 1 . blending (insects were blended for $2 \mathrm{~min}$ by a homogenizer), 2. freezing (placing the insects at $-20^{\circ} \mathrm{C}$ for $6 \mathrm{~h}$ ), 3. carbon dioxide treatment (a plastic container containing the insects was filled with $100 \% \mathrm{CO}_{2}$ and left at room temperature for $120 \mathrm{~h}$ ), 4 . vacuum (insects were placed under a vacuum for $120 \mathrm{~h}$ ), 5 . blanching (insects were immersed in boiling water for $40 \mathrm{~s}$ ) and $6 . \mathrm{CO}_{2}$ plus blanching (insects were treated with $\mathrm{CO}_{2}$ for $10 \mathrm{~min}$ before the blanching procedure was performed). Then, insect samples were dried at $60{ }^{\circ} \mathrm{C}$ for $48 \mathrm{~h}$, ground to a size of $1 \mathrm{~mm}$ and kept at $-20^{\circ} \mathrm{C}$ (except the sample for microbial analysis). This study was conducted following the standard guidelines approved by the Institutional Animal Care and Use Committee of Kasetsart University, Bangkok, Thailand (ACKU63-VET-008).

\subsection{Microbial Analysis}

BSFs after killing by different methods (before they were dried) were collected into sterile tubes. The samples were immediately transported to the laboratory in Kasetsart University Veterinary Teaching Hospital for bacterial culture and analysis in triplicate. The insect samples were homogenized in sterile phosphate-buffered saline (PBS, $\mathrm{pH}=7.4$ ), diluted and then the total viable count was identified by following the instructions for $3 \mathrm{M}^{\mathrm{TM}}$ Petrifilm ${ }^{\mathrm{TM}}$ Aerobic Count Plates (3M Microbiology Co.Ltd. St. Paul, MN, USA). The bacteria species or genus was identified based on its biochemical reaction following the guidelines of $\mathrm{API}^{\circledR}$ (bioMérieux, Inc., Durham, NC, USA).

\subsection{Chemical Compositions and Physicochemical Properties}

\subsubsection{Chemical Compositions}

The proximate composition (moisture (method no. 934.01, Natural Hot Air Oven NDO-450ND, Eyela, Tokyo, Japan), crude protein (method no. 2001.11, KJELTEC SYSTEM 1002 Distilling Unit and 2020 Digestor, Tecator, Denmark), ether extract (method no. 920.39, Soxtec system HT 1043, Tecator, Denmark), crude fiber (method no. 962.09, FIBERTEC SYSTEM M 1020 Hot extractor and 1021 Cold extractor, Tecator, Denmark), crude ash (method no. 942.05, Furnace, VULCAN A-1750, Vulcan electric, USA) and nitrogen-free extract (NFE, based on calculation)) of the BSF dried samples was determined in triplicate using the standard methods as described by the Association of Official Analytical Chemists [12].

\subsection{2. $\mathrm{PH}$ and Color}

The $\mathrm{pH}$ was measured in duplicate by homogenizing $1 \mathrm{~g}$ of BSF powder in $9 \mathrm{~mL}$ of 15 -ohm pure distilled water. The $\mathrm{pH}$ of the homogenate was monitored by using a digital $\mathrm{pH}$-meter (SevenCompact S220, Mettler Toledo, Ayer Rajah Crescent, Singapore). The color (lightness—L*, 
redness- $\mathrm{a}^{*}$, yellowness- $\mathrm{b}^{*}$ values; CIE 1976) was measured in duplicate with a portable colorimeter Chroma Meter CR-400 Minolta (Minolta Sensing Inc., Osaka, Japan).

\subsection{Enzymatic and Non-Enzyme Browning Reaction}

\subsubsection{Enzymatic Browning Reaction}

Five grams of sample were mixed with $10 \mathrm{~mL}$ of $50 \mathrm{mM}$ phosphate buffer at $\mathrm{pH} 6.0$ and homogenized in an ice bath. The homogenate was centrifuged at $2800 \mathrm{~g} \mathrm{~m}$ for $10 \mathrm{~min}$ at $4{ }^{\circ} \mathrm{C}$ and the supernatant kept for analysis of tyrosinase activity. Next, $1.2 \mathrm{~mL}$ of $50 \mathrm{mM}$ phosphate buffer at $\mathrm{pH}$ 6.0 with $800 \mu \mathrm{L}$ of $10 \mathrm{mM} \mathrm{L-DOPA}$ (substrate for tyrosinase) was added to $50 \mu \mathrm{L}$ of the supernatant, $250 \mu \mathrm{L}$ of enzyme and substrate and the reaction incubated at $30^{\circ} \mathrm{C}$ for $5 \mathrm{~min}$ in a microplate reader (Synergy H1 Hybrid Multi-Mode Microplate Reader, BioTek, Winooski, VT, USA). Absorbance was measured at $475 \mathrm{~nm}$. One unit of enzyme corresponds to the amount that catalyzes the transformation of $10 \mathrm{mM}$ of L-DOPA to dopachrome from tyrosinase per minute under standard conditions of $\mathrm{pH}$, temperature and substrate concentration [13].

\subsubsection{Non-Enzymatic Browning Reaction}

A modified version of the method described by Hwang et al. [14] was performed. Briefly, $1 \mathrm{~g}$ of sample was mixed with $7 \mathrm{~mL}$ of $50 \mathrm{mM} \mathrm{CaCl}$ and $50 \mathrm{mM}$ Tris- $\mathrm{HCl}(\mathrm{pH}$ 7.0). The mixture was vortexed and centrifuged at $10,000 \mathrm{~g}$ for $15 \mathrm{~min}$ at $4{ }^{\circ} \mathrm{C}$. To observe the progress of the Maillard reaction, the absorbance of $250 \mu \mathrm{L}$ of supernatant at 440 and $550 \mathrm{~nm}$ was recorded for the early and late Maillard reactions, respectively. The formula for calculating the browning index is Browning Index $(B I)=($ Absorbance at $440 \mathrm{~nm}-$ Absorbance at $550 \mathrm{~nm})$.

\subsection{Protein Oxidation}

Protein oxidation, as measured by the total carbonyl content, was evaluated at weeks 1,4 and 12 by derivatization using the method with slight modifications (Armenteros et al. [15]). The ground BSF samples ( $2 \mathrm{~g} / \mathrm{sample}$ ) were homogenized in $20 \mathrm{~mL}$ pyrophosphate buffer ( $\mathrm{pH} 7.4$ ) consisting of $2.0 \mathrm{mM} \mathrm{Na}_{4} \mathrm{P}_{2} \mathrm{O}_{7}, 10 \mathrm{mM}$ Tris-maleate, $100 \mathrm{mM} \mathrm{KCl}, 2.0 \mathrm{mM} \mathrm{MgCl}_{2}$ and $2.0 \mathrm{mM}$ Ethylene glycol tetraacetic acid (EGTA) using an ultra-turrax homogenizer for $30 \mathrm{~s}$. The homogenates were divided into two equal aliquots of $0.1 \mathrm{~mL}$. Then, proteins were precipitated in both aliquots by adding $1 \mathrm{~mL}$ of $10 \% \mathrm{TCA}$ and centrifuged for $5 \mathrm{~min}$ at $5000 \mathrm{~g}\left(4^{\circ} \mathrm{C}\right)$. The supernatants were removed, and one pellet was treated with $1 \mathrm{~mL} 2 \mathrm{~N} \mathrm{HCl}$ (for quantifying protein concentration) and the second pellet with an equal volume of $0.2 \%(w / v) \mathrm{DNPH}$ in $2 \mathrm{~N} \mathrm{HCl}$ (for carbonyl concentration measurement). Both samples were incubated for $1 \mathrm{~h}$ at room temperature (vortexed every $15 \mathrm{~min}$ ). After that, samples containing $0.2 \%$ DNPH were precipitated with $1 \mathrm{~mL}$ of $10 \%$ TCA and washed twice with $1 \mathrm{~mL}$ of 1:1 ethanol/ethyl acetate $(v / v)$, vortexed, and centrifuged for $5 \mathrm{~min}$ at $10,000 \mathrm{~g}\left(4^{\circ} \mathrm{C}\right)$. The pellets were then dissolved in $750 \mu \mathrm{L}$ of $20 \mathrm{mM}$ sodium phosphate buffer $\mathrm{pH} 6.5$ containing $6 \mathrm{M}$ guanidine hydrochloride, stirred and centrifuged for $2 \mathrm{~min}$ at $2800 \mathrm{~g}\left({ }^{\circ} \mathrm{C}\right)$ to remove insoluble fragments. Protein concentration was calculated from absorption at $750 \mathrm{~nm}$ using bovine serum albumin (BSA) as the standard (Lowry et al. [16]). A number of carbonyls were measured at $370 \mathrm{~nm}$ in a $250 \mu \mathrm{L}$ sample using a microplate reader and expressed as nmol of carbonyl per $\mathrm{mg}$ of protein using the adsorption coefficient for the protein hydrazones $\left(21.0 \mathrm{mM}^{-1} \mathrm{~cm}^{-1}\right)$.

\subsection{Fat Acidity}

American Association for Clinical Chemistry (AACC) [17] procedures were followed with slight modifications to determine fat acidity. Briefly, $2 \mathrm{~g}$ of sample powder was dried at $110^{\circ} \mathrm{C}$ for $2 \mathrm{~h}$ and the weight was recorded. The Sample was transferred to a thimble, which was plugged with cotton. For fat extraction, $50 \mathrm{~mL}$ of petroleum ether was added. The Soxtec method was used for extraction, and the solvent was evaporated. The extract was dissolved in $50 \mathrm{~mL}$ of toluene-alcohol-phenolphthalein (TAP) 
solution and placed in a $250 \mathrm{~mL}$ flask. The extract solution was titrated with $0.0178 \mathrm{~N} \mathrm{KOH}$ to the endpoint matching the standard color.

\subsection{Storage Trail}

\subsubsection{Lipid Oxidation}

Lipid oxidation was measured at weeks 1 and 4 according to the method of Larouche et al. [8]. Thiobarbituric acid-reactive substances (TBARs) were measured in BSF powder as follows: $0.5 \mathrm{~g}$ of each ground BSF powder (TBARs) homogenized in $10 \mathrm{~mL}$ of cold $1.15 \%$ phosphoric acid was centrifuged at $1008 \mathrm{~g}$ for $10 \mathrm{~min}$ at $4{ }^{\circ} \mathrm{C}$. A $400 \mu \mathrm{L}$ aliquot of supernatant was mixed with $1 \%$ TBARs and $0.1 \mathrm{mM}$ of butylated hydroxytoluene in $0.05 \% \mathrm{NaOH}$. All tubes were then treated with $200 \mu \mathrm{L}$ of $7 \%$ phosphoric acid and boiled for $15 \mathrm{~min}$. The reaction mixtures were cooled in an ice bath for $10 \mathrm{~min}$ and placed in the dark, then $1.5 \mathrm{~mL}$ of n-butanol was added and the mixture centrifuged (Hermile Z233 MK-2, Wehingen, Germany) at $448 \mathrm{~g}$ for $5 \mathrm{~min}$ at $4{ }^{\circ} \mathrm{C}$. Activity was evaluated with a microplate reader at $532 \mathrm{~nm}$ (Synergy H1 Hybrid Multi-Mode Microplate Reader, BioTek, Winooski, VT), that measured the absorbance of TBARs and a 1,1,3,3-tetraethoxypropane calibration curve (Botsoglou et al. [18]). Oxidation products were quantified as malondialdehyde (MDA) equivalents ( $\mu \mathrm{g}$ MDA $/ \mathrm{kg}$ BSF powder).

\subsubsection{In Vitro Digestibility}

In vitro digestibility procedures for swine were modified from Kong et al. [19], which consists of a two-step method. In the first step, $0.5 \mathrm{~g}$ of ground sample was mixed with $17.5 \mathrm{~mL}$ of stimulate gastric fluid (SGF, containing $25 \mathrm{~mL}$ of $0.1 \mathrm{M}$ sodium phosphate buffer $\mathrm{pH} 6.0$ and $10 \mathrm{~mL}$ of $0.2 \mathrm{M} \mathrm{HCl}$ $\mathrm{pH} 7.0$, adjusted to $\mathrm{pH} 2.0$ with $1 \mathrm{M} \mathrm{HCl}$ or $\mathrm{NaOH}$ ) to simulate digestion conditions in the stomach. Then, $0.5 \mathrm{~mL}$ of 5 chloramphenicol was added and $0.5 \mathrm{~mL}$ of freshly made pepsin solution $(10 \mathrm{mg} / \mathrm{mL}$, pepsin from porcine gastric mucosa) was also added. The reaction mixture was incubated in a shaking incubator at $39^{\circ} \mathrm{C}$ for $6 \mathrm{~h}$. In the second step, to stop the reaction of SGF and simulate digestion in the small intestine, $7.5 \mathrm{~mL}$ of simulated intestinal fluid solution (SIF, containing $10 \mathrm{~mL}$ of $0.2 \mathrm{M}$ sodium phosphate buffer solution $\mathrm{pH} 6.8$ and $5 \mathrm{~mL}$ of $0.6 \mathrm{M} \mathrm{NaOH}$, adjusted to $\mathrm{pH} 7.0$ ) was mixed with $0.5 \mathrm{~mL}$ of pancreatin solution $(50 \mathrm{mg} / \mathrm{mL}$ of pancreatin from porcine pancreas) and incubated for $18 \mathrm{~h}$ at $39^{\circ} \mathrm{C}$ in a shaking incubator. After incubation, $2.5 \mathrm{~mL}$ of $20 \%$ trichloroacetic acid was added, and the sample was left for $30 \mathrm{~min}$ at room temperature to stop the enzyme reaction and precipitate the indigestible protein. One milliliter aliquots of supernatants were kept at $-20{ }^{\circ} \mathrm{C}$ for analysis of free amino acids (in vitro protein digestibility, IVPD) and maltose (in vitro carbohydrate digestibility, IVCD), performed according to the trininobenzene sulfonic acid (TNBS) and dinitrosalicylic acid (DNS) methods, respectively. The IVPD and IVCD studies in the supernatant were described in Sansuwan et al. [20]. Residues were then filtered through a filter glass crucible in a Fibertec System cold extraction unit. The samples were rinsed twice or more with distilled water. Next, two additional rinses with $30 \mathrm{~mL}$ of $95 \%$ ethanol and $30 \mathrm{~mL}$ of $99 \%$ acetone were performed in the filter crucible. Glass filter crucibles with undigested residues were dried at $60-70{ }^{\circ} \mathrm{C}$ for $24 \mathrm{~h}$ for determination of crude protein and organic matter digestibility in the sediment as described in Kovitvadhi et al. [21].

\subsection{Statistical Analysis}

All statistical analyses in this study were performed by using R-statistic with the Rcmdr Package (R Development Core Team [22]). Statistical significance was accepted at $p<0.05$. One-way analysis of variance was performed for data with a normal distribution and homogeneity of variance, with killing methods as fixed factors, to determine the consequences on BSF qualities. Duncan's new multiple range test served as a post hoc test. 


\section{Results}

\subsection{Microbial Analysis in BSF Larvae after Killing}

An approximately 10-fold lower microbial load was observed in the blanching and $\mathrm{CO}_{2}$ plus blanching groups compared with other groups. Several specific bacterial species were discovered in the BSFs, except when killing methods with heating treatment (blanching and the $\mathrm{CO}_{2}$ plus blanching methods) were used. No Salmonella sp. was observed in any group in this study (Table 1).

Table 1. Microbial load after killing black soldier fly (BSF) larvae from different killing methods.

\begin{tabular}{|c|c|c|c|c|c|c|}
\hline \multirow{3}{*}{ Microorganism } & \multicolumn{6}{|c|}{ Killing Methods } \\
\hline & \multicolumn{2}{|c|}{ Mechanical } & \multicolumn{2}{|c|}{ Asphyxiation } & \multicolumn{2}{|r|}{ Heat } \\
\hline & Blending & Freezing & $\mathrm{CO}_{2}$ & Vacuum & Blanching & $\mathrm{CO}_{2}$ Plus Blanching \\
\hline TVC (CFU/g sample) & $4.1 \times 10^{10}$ & $1.6 \times 10^{10}$ & $4.8 \times 10^{10}$ & $3.5 \times 10^{10}$ & $7.7 \times 10^{9}$ & $7.2 \times 10^{9}$ \\
\hline Acinetobacter sp. & $\bullet$ & $\bullet$ & $\bullet$ & $\bullet$ & $\bullet$ & $\bullet$ \\
\hline Bacillus cereus & - & - & - & - & - & - \\
\hline Enterobacter aerogenes & $\bullet$ & - & - & - & - & - \\
\hline Enterobacter cloacae & - & - & - & $\bullet$ & - & - \\
\hline Escherichia coli & $\bullet$ & $\bullet$ & $\bullet$ & $\bullet$ & - & - \\
\hline Klebsiella pneumoniae & $\bullet$ & - & - & - & - & - \\
\hline Proteus mirabilis & - & $\bullet$ & $\bullet$ & - & - & - \\
\hline
\end{tabular}

\subsection{Chemical Composition and Physicochemical Parameters of BSF Larvae Meal}

The results for the effects of different killing methods on BSF qualities (proximate compositions and their parameters) are summarized in Table 2. Statistically significant differences were presented in the chemical compositions of BSFs between the groups $(p<0.001)$ except in crude ash and fiber $(p>0.05)$. The proportions of ether extract and crude protein in the blending group were lower than in the others $(p<0.001)$. On the other hand, the blending group was higher in nitrogen-free extract, followed by the freezing, $\mathrm{CO}_{2}$ plus blanching, blanching, $\mathrm{CO}_{2}$ and vacuum groups $(p<0.001)$ as shown in Table 2.

The $\mathrm{pH}$ value after killing declined greatly in the blending group, whereas the killing methods involving heating (blanching and the $\mathrm{CO}_{2}$ plus blanching methods) and other techniques affected the $\mathrm{pH}$ only slightly or caused a moderate decrease, respectively $(p<0.001)$.

The highest rate of non-enzymatic browning was observed in the blending group, whereas the vacuum, freezing, $\mathrm{CO}_{2}$, blanching and $\mathrm{CO}_{2}$ plus blanching methods exhibited lower rates of browning $(p<0.001)$. On the one hand, the highest rate of enzymatic browning was found in the blending group, followed by $\mathrm{CO}_{2}$, vacuum and freezing, while this chemical reaction was not present in the blanching and $\mathrm{CO}_{2}$ plus blanching groups $(p<0.001)$.

BSFs killed by the blanching and $\mathrm{CO}_{2}$ plus blanching methods were lighter in color than those killed by other methods $(p<0.001)$. Most of the BSFs had low redness and yellowness values; however, the blending, blanching and $\mathrm{CO}_{2}$ plus blanching groups were higher in these values than the others $(p<0.001)$. Three color groups were formed on the basis of the hue angle values, which were as follows: 1. blending and blanching, 2. freezing, vacuum and $\mathrm{CO}_{2}$ plus blanching and $3 . \mathrm{CO}_{2}(p<0.001)$. The colorfulness (Chroma) in descending order was blanching, $\mathrm{CO}_{2}$ plus blanching, blending, vacuum, freezing and $\mathrm{CO}_{2}(p<0.001)$. A low value of protein oxidation was presented in the $\mathrm{CO}_{2}$, vacuum, blanching and $\mathrm{CO}_{2}$ plus blanching groups, whereas a low value of fat acidity was revealed only in the blanching and $\mathrm{CO}_{2}$ plus blanching groups compared with the others $(p<0.01)$ as shown in Table 2. 
Table 2. Proximate compositions and physicochemical properties of BSF larvae after killing with different processing.

\begin{tabular}{|c|c|c|c|c|c|c|c|c|}
\hline \multirow{3}{*}{ Parameters } & \multicolumn{6}{|c|}{ Killing Methods } & \multirow{3}{*}{ SEM } & \multirow{3}{*}{$p$} \\
\hline & \multicolumn{2}{|c|}{ Mechanical } & \multicolumn{2}{|c|}{ Asphyxiation } & \multicolumn{2}{|r|}{ Heat } & & \\
\hline & Blending & Freezing & $\mathrm{CO}_{2}$ & Vacuum & Blanching & $\mathrm{CO}_{2}$ Plus Blanching & & \\
\hline \multicolumn{9}{|l|}{ Proximate composition } \\
\hline Dry matter (\%FM) & $95.7^{\mathrm{ab}}$ & $96.6^{c}$ & $96.1^{b c}$ & $95.5^{\mathrm{a}}$ & $97.4^{\mathrm{d}}$ & $97.2^{\mathrm{d}}$ & 0.181 & 0.001 \\
\hline Crude ash (\%DM) & 7.29 & 7.30 & 7.50 & 7.44 & 7.04 & 6.90 & 0.068 & 0.47 \\
\hline Ether extract (\%DM) & $25.7^{\mathrm{a}}$ & $27.3^{\mathrm{ab}}$ & $28.1^{b}$ & $29.1^{b}$ & $28.1^{b}$ & $28.4^{\mathrm{b}}$ & 0.331 & 0.001 \\
\hline NFE (\%DM) & $17.5^{\mathrm{d}}$ & $11.4^{\mathrm{c}}$ & $8.28^{b}$ & $2.69^{a}$ & $8.95^{b c}$ & $10.3^{b c}$ & 1.074 & 0.001 \\
\hline \multicolumn{9}{|l|}{ Physicochemical properties } \\
\hline $\mathrm{pH}$ value & $6.14^{\mathrm{a}}$ & $6.48^{\mathrm{c}}$ & $6.43 \mathrm{bc}$ & $6.36^{\mathrm{b}}$ & $7.31^{\mathrm{d}}$ & $7.47^{\mathrm{e}}$ & 0.128 & 0.001 \\
\hline \multicolumn{9}{|l|}{ Browning reaction } \\
\hline Enzymatic (U) & $2.65^{\mathrm{d}}$ & $0.83^{b}$ & $1.53^{c}$ & $1.52^{\mathrm{c}}$ & $\mathrm{ND}^{\mathrm{a}}$ & $\mathrm{ND}^{\mathrm{a}}$ & 0.246 & 0.001 \\
\hline $\mathrm{b}^{*}$ (Yellowness) & $0.80^{\mathrm{c}}$ & $0.47^{\mathrm{b}}$ & $0.43^{\mathrm{a}}$ & $0.48^{\mathrm{b}}$ & $0.85^{\mathrm{d}}$ & $0.80^{\mathrm{c}}$ & 0.043 & 0.001 \\
\hline Hue & $1.30^{\mathrm{a}}$ & $1.41^{\mathrm{b}}$ & $1.49^{c}$ & $1.40^{\mathrm{b}}$ & $1.31^{\mathrm{a}}$ & $1.41^{\mathrm{b}}$ & 0.016 & 0.001 \\
\hline Chroma & $0.83^{c}$ & $0.48^{\mathrm{b}}$ & $0.43^{\mathrm{a}}$ & $0.49^{b}$ & $0.88^{\mathrm{d}}$ & $0.81^{\mathrm{c}}$ & 0.046 & 0.001 \\
\hline Fat acidity & $84.9^{c}$ & $13.9^{b}$ & $10.4^{\mathrm{b}}$ & $12.2^{b}$ & $0.77^{\mathrm{a}}$ & $0.55^{\mathrm{a}}$ & 7.527 & 0.001 \\
\hline Protein oxidation & $0.81 \mathrm{bc}$ & $1.03^{\mathrm{c}}$ & $0.42^{\mathrm{a}}$ & $0.51^{\mathrm{ab}}$ & $0.60^{\mathrm{ab}}$ & $0.71^{\mathrm{ab}}$ & 0.060 & 0.01 \\
\hline
\end{tabular}

NFE: nitrogen free extract; SEM: standard error of mean; enzymatic browning reaction was expressed as U; BI: Browning Index; fat acidity was expressed as $\mathrm{mg}$ of $\mathrm{KOH}$ per $100 \mathrm{mg}$ of dry sample; protein oxidation was expressed in $\mathrm{nM}$ carbonyl. a,b,c,d,e Different superscripts in the same row indicate statistically significant differences $(p<0.05)$ by using Duncan's multiple range test as post hoc analysis.

\subsection{Lipid Peroxidation of BSF after Killing}

The ascending trend for lipid peroxidation was presented during the storage period (Figure 1). High values of lipid peroxidation were observed in blending, vacuum, freezing and $\mathrm{CO}_{2}$, respectively $(p<0.001)$ compared to the blanching and $\mathrm{CO}_{2}$ plus blanching methods which were clearly lower at 28 days after storage.

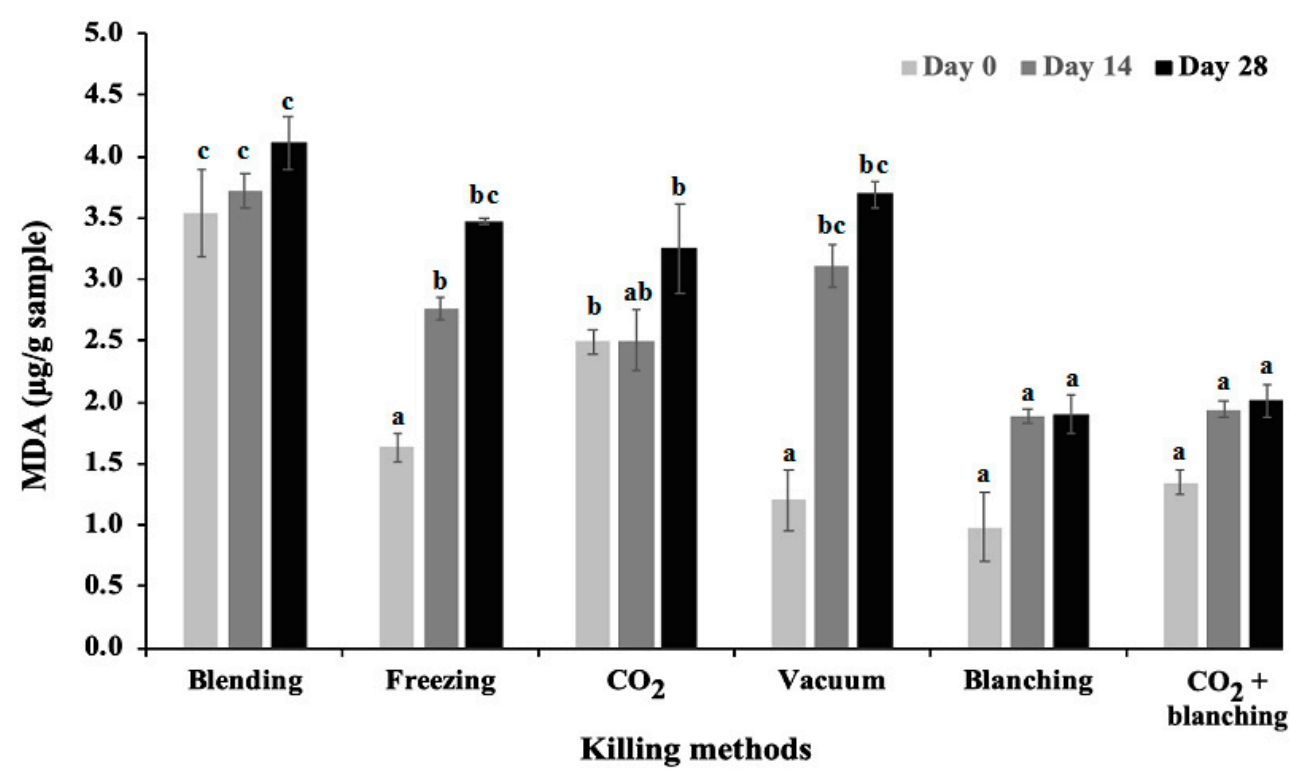

Figure 1. Storage time on thiobarbituric acid-reactive substance (TBAR) contents of BSFs after storage at $4{ }^{\circ} \mathrm{C}$ during $0(\square), 14(\square)$ and 28 days $(\square)$. The differences on the superscript at the same day represent statistically significant differences between killing methods $(p<0.05)$. 


\subsection{In Vitro Digestibility of BSF Larvae Meal}

Table 3 presents the in vitro digestibility performances based on supernatant or end-product evaluation of carbohydrates and was the highest in the blending group, followed by the freezing, vacuum and $\mathrm{CO}_{2}$ groups, whereas the blanching and $\mathrm{CO}_{2}$ plus blanching methods had low values for this parameter $(p<0.05)$. In contrast, the highest value of in vitro crude protein digestibility was illustrated in the $\mathrm{CO}_{2}$ plus blanching group $(p<0.001)$. The lowest in vitro digestibility of dry matter and crude protein based on the sediment calculation method was found in the blending group $(p<0.05)$.

Table 3. In vitro digestibility of BSF larvae meal as raw materials.

\begin{tabular}{|c|c|c|c|c|c|c|c|c|}
\hline \multirow{3}{*}{ In Vitro Digestibility } & \multicolumn{6}{|c|}{ Killing Methods } & \multirow{3}{*}{ SEM } & \multirow{3}{*}{$p$} \\
\hline & \multicolumn{2}{|c|}{ Mechanical } & \multicolumn{2}{|c|}{ Asphyxiation } & \multicolumn{2}{|r|}{ Heat } & & \\
\hline & Blending & Freezing & $\mathrm{CO}_{2}$ & Vacuum & Blanching & $\mathrm{CO}_{2}$ Plus Blanching & & \\
\hline \multicolumn{9}{|l|}{ Supernatant } \\
\hline IVCD & $19.5^{\mathrm{d}}$ & $13.2^{\mathrm{c}}$ & $8.42^{b}$ & $11.2^{b c}$ & $2.54^{\mathrm{a}}$ & $1.87^{\mathrm{a}}$ & 1.521 & 0.001 \\
\hline IVPD & $122^{a}$ & $112^{\mathrm{a}}$ & $124^{\text {a }}$ & $129^{a}$ & $133^{\text {a }}$ & $166^{b}$ & 5.374 & 0.04 \\
\hline \multicolumn{9}{|l|}{ Sediment (\%) } \\
\hline Dry matter & $53.3^{\mathrm{a}}$ & $59.4^{\mathrm{b}}$ & $57.1^{\mathrm{ab}}$ & $61.0^{\mathrm{b}}$ & $56.1^{\mathrm{ab}}$ & $59.8^{\mathrm{b}}$ & 0.868 & 0.04 \\
\hline Crude protein & $31.3^{\mathrm{a}}$ & $48.9^{\mathrm{b}}$ & $53.1^{\mathrm{b}}$ & $54.8^{\mathrm{b}}$ & $52.9^{\mathrm{b}}$ & $51.9^{\mathrm{b}}$ & 2.094 & 0.001 \\
\hline
\end{tabular}

SEM: standard error of mean; IVCD: in vitro carbohydrate digestibility (mM of D-maltose equivalence per $\mathrm{g}$ feed); IVPD: in vitro protein digestibility (mM of DL-alanine equivalence per $\mathrm{g}$ feed). ${ }^{\mathrm{a}, \mathrm{b}, \mathrm{c}, \mathrm{d}} \mathrm{d}$ Different superscripts in the same row indicate statistically significant differences $(p<0.05)$ by using Duncan's multiple range test as post hoc analysis.

\section{Discussion}

\subsection{Impact of Killing Method on Microbial Load}

Heating at the appropriate temperature $\left(100^{\circ} \mathrm{C}\right)$ and for the appropriate duration $(40 \mathrm{~s})$ has a major influence on the reduction of microbial loads in BSFs after killing [8], which is able to reduce the total aerobic viable count by around 10 times compared with other methods. As we know, the growth rate of bacteria is reduced in a cold temperature environment, which can result in a low microbial load in BSFs after killing by freezing methods [8]. The total bacterial count in the blending method was similar to that of the asphyxiation method in this trial; however, the study of Larouche et al. [8] reported a lower value of this parameter in the blending group than with the asphyxiation method. The blending method provided a homogenized sample which destroyed the cell structure and increased the contact surface between bacteria and substrates which could promote bacterial growth.

Black soldier fly prepupae can survive under asphyxiation for long periods, in contrast to house crickets (Acheta domestica [23]). Therefore, this technique promoted anaerobic conditions and prolonged the killing process at room temperature, which led to selective growth of a specific group of microbes. For these reasons, higher microbial loads of facultative anaerobic bacteria and anaerobic bacteria were observed in the asphyxiation treatment groups [8]. The rearing method and biosecurity system are important factors which correlate with the microbial load and community in BSFs [24]. The absence of contamination by Acinetobactor sp., Bacillus cereus and Salmonella spp. during cultivation and processing contributed to the absence of growth of these bacteria in BSFs. The absence of Salmonella spp. in raw materials is an important quality and safety indicator according to the regulations in several countries; therefore, good agricultural and biosafety practices must be strictly performed [25] to prevent contamination along the production process. However, contamination with coliforms and other pathogenic bacteria was discovered in this study, which came from the BSF substrates. Heat treatment was suggested to reduce these microorganisms.

The overall number of bacteria in this study seemed higher than in the study of Larouche et al. [8]. The different outcome may have been a consequence of the bacterial culture being immediately performed after the end of the killing procedures in this study, whereas Larouche et al. [8] cultured 
microbes from a freeze-thawed sample, which would have decreased the growth rate of microbes. The acidic conditions of end products promote a prolonged shelf life and reduce the microbial growth rate [26], which relates to the activity of acid-producing bacteria such as Lactobacillus sp. [8]. As described above, heat treatment reduced the microbial load, whereas asphyxiation promoted bacterial growth.

High $\mathrm{pH}$ was observed in heat-treatment groups, and low $\mathrm{pH}$ was presented in asphyxiation groups, which was comparable to other research studies [8]. The total viable count after killing by heat treatment was still higher than the limit based on the regulation on animal feed of Thailand, which must be lower than $8 \times 106 \mathrm{CFU} / \mathrm{g}$ fresh matter [25], therefore a further hot drying process with appropriate storage conditions should be performed to reduce microbial loads. From our suggestion, the pathogenic bacteria were observed in the black soldier fly prepupae after killing; therefore, further heat treatments and/or drying processes must be performed to prevent infection in animals and also cross contamination of humans, which is a public health concern.

\subsection{Impacts of Killing Methods on Chemical Composition and Physicochemical Properties}

\subsubsection{Proximate Compositions}

The blanching procedure decreases the moisture levels of the end product compared with other methods, which has the benefit of reducing the cost of the drying process [8]. However, oven drying and grinding was performed before moisture evaluation. The same results were observed in this study, in which the reduction of water holding capacity was caused by protein denaturation after heat treatment $[8,27]$. The lowest ash or mineral components were presented in the blanching group compared to other groups in this and another study [8], which could be a consequence of heat treatment conserving organic matter in a higher proportion compared with other techniques. The effects of different killing methods on ether extract composition in this study were similar to the study of Montevecchi et al. [10] in which blanching and freezing produced products higher in lipids than blending. On the other hand, Larouche et al. [8] reported that blanching produced the lowest lipid levels compared to asphyxiation, freezing and blending. However, no difference in fat composition between freezing and blanching was also published [7]. Differences in insect preparation, extraction, storage and lipid determination are the likely causes of these diverse outcomes. A lower amount of crude protein was observed in blanching compared with freezing in this and another study [9]. However, blending contained the lowest crude protein content. Freezing and blanching did not affect total amino acids of Tenebrio molitor (TM) [28]. In terms of overall results and information, blending was the worst method for its inability to preserve the nutrients in BSFs compared with other methods.

\subsubsection{Physicochemical Properties}

The color of BSFs is an absolutely important factor in terms of farmer acceptance because insect meal in light brown shades of beige, tan and khaki is preferred by farmers or users, whereas dark brown or black is not accepted. The browning reaction and melanization are the chemical reactions which influence color alterations after killing and processing [8,9]. The enzymatic browning reaction or polyphenol oxidation in an aerobic condition promoted the darkish effects on BSFs [29,30]. Moreover, the complex between amino acids and reducing sugars was present after the drying process, leading to a darker color, which is called the Maillard reaction or non-enzymatic browning reaction [31,32]. Melanin was produced as the end product of melanization, which was the innate immune response of insects to harmful environments and promoted a darker color of BSF [9]. The low level of browning reaction in BSFs with heat treatment was caused by enzyme destruction by heat [8,9]. Heat treatment can only terminate the enzymatic browning reaction [31,32]; however, the decline of the non-enzymatic browning reaction was observed in this study, which may have resulted from a short time available for metabolism, as the killing process was rapid by heating [8]. 
The slow killing methods without an enzyme destruction protocol, such as freezing and asphyxiation, promoted the activation of several metabolic processes, mainly lipolysis, melanization and browning, which led to a darker color [9]. The darker color developed immediately after blending the prepupae of BSFs because the enzymatic browning reaction between substrates and enzymes released from cell destruction was increased in the homogenized samples. Therefore, the darkest color was found in the blending procedure [8]. For these reasons, the BSF color is greatly influenced by the killing procedures. The lightest BSFs were observed in the hot treatment group, which agreed with other research studies [8,9]. Therefore, limitation on the initiation of the browning reaction and melanisation was a major factor to prevent color alteration of BSFs.

Blanching was considered the best killing method to preserve the integrity and quality of BSFs, which agreed with the report of Larouche et al. [8]. In contrast, Montevecchi et al. [10] reported blending or grinding of live black soldier fly prepupae as the best killing method due to homogenization of BSF prepupae in a specific solvent mixture that was water free and composed of chloroform-methanol 2:1 $(v / v)$, from which water was subtracted by methanol slowing down enzymatic activity (hydrolytic), especially lipase for generated reaction of fat acidity and lipid oxidation. The mechanisms by which different killing procedures affect BSF quality were described in detail. Fat acidity was used to represent the amount of free fatty acids in samples which correlated with lipase activity respectively [10], the fat acidity in the asphyxiation and freezing groups was higher than that in the heat treatment group by approximately three and ten times respectively, which agreed with this study $[7,8]$. In this study, the extremely high value of fat acidity was observed in the blending group, which represented the high lipase activity in this sample. The freezing technique only decreased lipase activity, which remains in a low temperature environment $\left(5^{\circ} \mathrm{C}\right)$, even at $-30^{\circ} \mathrm{C}$ [33]. On the other hand, heat treatment can destroy lipase, which minimizes fat acidity and prevents the $\mathrm{pH}$ reduction after killing compared with other methods.

Another parameter representing the integrity of BSFs is lipid oxidation; the high activity of this chemical reaction promotes several adverse outcomes for consumers such as nutrient loss, lower digestibility of products, rancidity, carcinogen substances and toxicity [34]. The rates of lipid oxidation from killing procedures with heat treatments were reduced by around 1-2 times compared with other methods in this and another study [8], whereas the highest lipid oxidation value was presented in the blending group. Based on the standard, the BSFs subjected to heat and vacuum treatments were considered not rancid $(<1.5 \mathrm{mg} \mathrm{MDA} / \mathrm{kg}$ ) after an oven drying process [35]. Only BSFs subjected to the heat treatment procedure were still slightly rancid (1.6-3.6 mgMDA $/ \mathrm{kg}$ ) after storage at $4{ }^{\circ} \mathrm{C}$ for 28 days, whereas BSFs subjected to asphyxiation, freezing and blending were recognized as rancid products ( $>3.6 \mathrm{mgMDA} / \mathrm{kg}$ ) [35]. The higher carbonyl content (protein oxidation) obtained in the freezing method than in the heating method in the current study may be due to the process being initiated by hydrogen abstraction from the alpha-carbon in a peptide chain. If two protein radicals are in close proximity, they may crosslink with one another via a radical formed under high-temperature conditions, which generates free radicals (carbonyl production). The terminated free radicals were conjugated (i.e., radical-radical interaction). Moreover, lipid radicals (lipid oxidation) can also abstract hydrogen from protein functional groups, which can result in lipid protein cross-linking [36], suggesting a possible reduced capacity for protein and lipid oxidation via the indirect effect of radicals from the heating method.

\subsection{Impacts of Killing Methods on In Vitro Digestibility}

The digestibility of BSFs is an important factor in their use as a feed ingredient, which could promote nutrient utilization efficiency and decrease the amount of manure, promoting environmentally friendly ideas. The consequences of initiation of the browning reaction and melanization were the binding between amino acids (mainly lysine) and reducing sugar, which this complex was unable to digest with digestive enzymes from animals [9]. Moreover, protein aggregation was found after melanization, which decreased protein solubility and digestibility [9]. However, the occurrence of 
some chemical reactions, mainly melanization from the stress response during freezing, was activated, which could lead to lower digestibility of BSFs as described above [9]. However, lower crude protein digestibility was observed in blanching compared with freezing in this study and others [9]. Although blanching can destroy several enzymes, heat also can denature the protein, causing aggregation and resistance to digestion by animal enzymes, which could be the cause of this consequence. Interestingly, the end products of protein digestibility in the supernatant of in vitro digestibility were found in the highest values in the $\mathrm{CO}_{2}$ plus blanching method compared with other methods. Treatment with $\mathrm{CO}_{2}$ for short periods before submersion in boiling water may influence this outcome. However, the fact that insects were unconscious and/or had a lower response to stress during $\mathrm{CO}_{2}$ treatment should be investigated further as the cause.

\subsection{Impacts of Killing Methods on Storage Trail (Lipid Oxidation Content)}

The sample characteristics and environmental conditions during storage were the major factors which influenced the level of lipid oxidation [34]. The occurrence of free radicals and tissue damage led to lipid oxidation from the reaction between lipids and enzymes [37,38]. Medium-chain saturated fatty acids, called lauric acids, were a major component of the fatty acid profiles of BSFs, which have a low ratio of polyunsaturated fatty acids compared with vegetable oils $[5,6]$. However, saturated fatty acids were the main component of BSFs. The high proportion of lipids was observed in BSFs depending on their diets $[5,6]$. Therefore, the characteristics of BSFs carry the risk of presenting lipid oxidation. Moreover, inappropriate storage conditions of high oxygen, temperature, water activity and optimal $\mathrm{pH}$ for metabolism can accelerate lipid oxidation [34].

The freezing method was only able to decrease the metabolic enzyme activity but did not terminate it; therefore, lipid oxidation was still occurring $[9,10]$. Moreover, the metabolomics approach confirmed that several enzymatic methods were activated during killing by freezing because the adaptation to survive in a cold environment was established as the insect was still alive during this slow killing procedure [9]. In addition, cell membranes were damaged by ice crystals obtained from the slow freezing procedures, which led to the risk of higher lipid oxidation $[8,10]$. On the one hand, the freezing method deteriorated the lipid quality of yellow mealworm (Tenebrio molitor: TM) [39].

The reduction in lipid oxidation on the first day after oven drying and grinding was observed with the vacuum procedure because lipid oxidation was delayed by the lack of oxygen [34]. Blanching was considered as the best procedure to conserve the fat integrity of BSFs based on the results in this study and others $[7,8]$ because heat treatment can destroy the enzymes which reduce the lipid oxidation process. On the other hand, blending was suggested as a way to conserve fat quality, whereas blanching caused severe deterioration of tissues, leading to high lipid oxidation [10]. According to this information and the results of this study, the lower proportion of lipids in blending methods compared with others [10] could be the cause of these different outcomes. However, further analysis could confirm this hypothesis.

\section{Conclusions}

Based on the research results, the blanching and $\mathrm{CO}_{2}$ plus blanching methods were suggested as the best procedures to kill black soldier fly prepupae to preserve product quality. Therefore, the blanching technique was suggested in terms of cost and benefits on product quality. However, the $\mathrm{CO}_{2}$ plus blanching method can be selected depending on the ethics and animal welfare regulations of each country. The lowest boiling timing should be identified $(<40 \mathrm{~s})$ to reduce the cost of production on a large scale. Moreover, the effects of killing methods on minerals, vitamins, amino acid and fatty acid profiles should be identified.

Author Contributions: Conceptualization, A.K.; methodology, A.K.; investigation, Y.Z. (Yongkang Zhen), P.C. and A.K.; data curation, A.K.; writing — original draft preparation, A.K.; writing-review and editing, Y.Z. (Yongkang Zhen), P.C., Y.Z. (Yu Zhang), M.W., W.V., C.P. and A.K.; project administration, A.K.; funding acquisition. All authors have read and agreed to the published version of the manuscript. 
Funding: This research was financially supported by the Thailand Science Research, Innovation and Office of National Higher Education Science Research and Innovation Policy Council (Thailand), the National Natural Science Foundation of China (31702107) and the Open Project Program of Jiangsu Key Laboratory of Zoonosis (No.R186).

Acknowledgments: The authors would like to humbly thank to Orgafeed Co. Ltd. (Bangkok, Thailand) for providing the samples. We declare that we have no financial or personal relationships with any people or organizations that could have inappropriately influenced our work.

Conflicts of Interest: The authors declare no conflict of interest.

\section{Abbreviations}

BSF: black soldier fly; TVC: total viable aerobic count; CFU: colony forming unit; NFE: nitrogen free extract; BI: Browning Index; TBAR: thiobarbituric acid-reactive substance; MDA: malondialdehyde; DNS: dinitrosalicylic acid; TNBS: trininobenzene sulfonic acid; IVCD: in vitro carbohydrate digestibility; IVPD: in vitro protein digestibility.

\section{References}

1. Makkar, H.P.; Tran, G.; Heuzé, V.; Ankers, P. State-of-the-art on use of insects as animal feed. Anim. Feed Sci. Technol. 2014, 197, 1-33. [CrossRef]

2. Gasco, L.; Biasato, I.; Dabbou, S.; Schiavone, A.; Gai, F. Animals Fed Insect-Based Diets: State-of-the-Art on Digestibility, Performance and Product Quality. Animals 2019, 9, 170. [CrossRef]

3. Sogari, G.; Amato, M.; Biasato, I.; Chiesa, S.; Gasco, L. The Potential Role of Insects as Feed: A MultiPerspective Review. Animals 2019, 9, 119. [CrossRef] [PubMed]

4. Biancarosa, I.; Liland, N.S.; Biemans, D.; Araujo, P.; Bruckner, C.G.; Waagbø, R.; Torstensen, B.E.; Amlund, H.; Lock, E.-J. Uptake of heavy metals and arsenic in black soldier fly (Hermetia illucens) larvae grown on seaweed-enriched media. J. Sci. Food Agric. 2017, 98, 2176-2183. [CrossRef] [PubMed]

5. Wang, Y.-S.; Shelomi, M. Review of Black Soldier Fly (Hermetia illucens) as Animal Feed and Human Food. Foods 2017, 6, 91. [CrossRef]

6. Beniers, J.; Graham, R. Effect of protein and carbohydrate feed concentrations on the growth and composition of black soldier fly (Hermetia illucens) larvae. J. Insects Food Feed 2019, 5, 193-199. [CrossRef]

7. Lolli, V.; Marseglia, A.; Sorci, A.; Bonzanini, F.; Lolli, V.; Maistrello, L.; Sforza, S. Influence of the killing method of the black soldier fly on its lipid composition. Food Res. Int. 2019, 116, 276-282. [CrossRef]

8. Larouche, J.; Deschamps, M.-H.; Saucier, L.; Lebeuf, Y.; Doyen, A.; Vandenberg, G.W. Effects of Killing Methods on Lipid Oxidation, Colour and Microbial Load of Black Soldier Fly (Hermetia illucens) Larvae. Animals 2019, 9, 182. [CrossRef]

9. Leni, G.; Caligiani, A.; Sforza, S. Killing method affects the browning and the quality of the protein fraction of Black Soldier Fly (Hermetia illucens) prepupae: A metabolomics and proteomic insight. Food Res. Int. 2019, 115, 116-125. [CrossRef]

10. Montevecchi, G.; Zanasi, L.; Masino, F.; Maistrello, L.; Antonelli, A. Black soldier fly (Hermetia illucens L.): Effect on the fat integrity using different approaches to the killing of the prepupae. J. Insects Food Feed 2020, 6, 121-131. [CrossRef]

11. Gjerris, M.; Gamborg, C.; Röcklinsberg, H. Ethical aspects of insect production for food and feed. J. Insects Food Feed 2016, 2, 101-110. [CrossRef]

12. Official Methods of Analysis of. Anal. Chem. 1980, 52, 148. [CrossRef]

13. Yang, Z; $\mathrm{Wu}, \mathrm{F}$. Catalytic properties of tyrosinase from potato and edible fungi. Biotechnology 2006, 5, 344-348.

14. Hwang, J.-Y.; Shue, Y.-S.; Chang, H.-M. Antioxidative activity of roasted and defatted peanut kernels. Food Res. Int. 2001, 34, 639-647. [CrossRef]

15. Armenteros, M.; Heinonen, M.; Ollilainen, V.; Toldrá, F.; Estévez, M. Analysis of protein carbonyls in meat products by using the DNPH-method, fluorescence spectroscopy and liquid chromatography-electrospray ionisation-mass spectrometry (LC-ESI-MS). Meat Sci. 2009, 83, 104-112. [CrossRef] [PubMed]

16. Lowry, O.H.; Rosebrough, N.J.; Farr, A.L.; Randall, R.J. Protein measurement with the Folin phenol reagent. J. Boil. Chem. 1951, 193, 265-275. 
17. AACC International. Approved Methods of Analysis, 11th ed.; Method 02-01.02. Fat acidity-General method. Approved October 3, 1984; re-approved November 3, 1999; revised 2009. Available online: https://methods.aaccnet.org/summaries/02-01-02.aspx (accessed on 5 March 2020).

18. Botsoglou, N.A.; Fletouris, D.J.; Papageorgiou, G.E.; Vassilopoulos, V.N.; Mantis, A.J.; Trakatellis, A.G. Rapid, Sensitive, and Specific Thiobarbituric Acid Method for Measuring Lipid Peroxidation in Animal Tissue, Food, and Feedstuff Samples. J. Agric. Food Chem. 1994, 42, 1931-1937. [CrossRef]

19. Kong, C.; Park, C.S.; Kim, B.G. Effects of an enzyme complex on in vitro dry matter digestibility of feed ingredients for pigs. SpringerPlus 2015, 4, 261. [CrossRef]

20. Sansuwan, K.; Kovitvadhi, S.; Thongprajukaew, K.; Ozorio, R.O.D.A.; Somsueb, P. Microwave irradiation and pelleting method affected feed chemical composition and growth performance and feed utilization of sex-reversed Nile tilapia, Oreochromis niloticus (L.). Aquac. Res. 2016, 48, 1836-1848. [CrossRef]

21. Kovitvadhi, A.; Chundang, P.; Thongprajukaew, K.; Tirawattanawanich, C.; Srikachar, S.; Chotimanothum, B. Potential of Insect Meals as Protein Sources for Meat-Type Ducks Based on In Vitro Digestibility. Animals 2019, 9, 155. [CrossRef]

22. Venables, W.N.; Ripley, B.D. Package MASS. Available online: http://www.r-project.org (accessed on 17 October 2012).

23. Clark, M.A.; Eaton, D.C. Effect of $\mathrm{CO}_{2}$ on neurons of the house cricket, acheta domestica. J. Neurobiol. 1983, 14, 237-250. [CrossRef] [PubMed]

24. Wynants, E.; Frooninckx, L.; Crauwels, S.; Verreth, C.; De Smet, J.; Sandrock, C.; Wohlfahrt, J.; Van Schelt, J.; Depraetere, S.; Lievens, B.; et al. Assessing the Microbiota of Black Soldier Fly Larvae (Hermetia illucens) Reared on Organic Waste Streams on Four Different Locations at Laboratory and Large Scale. Microb. Ecol. 2018, 77, 913-930. [CrossRef] [PubMed]

25. Ministry of Agriculture and Cooperatives. Animal Feed Quality Control ACT B.E.2558; Ministry of Agriculture and Cooperatives: Bangkok, Thailand, 2016. Available online: http://afvc.dld.go.th (accessed on 25 March 2020).

26. Minister of Justice. Division 27: Low-Acid Foods Packaged in Hermetically Sealed; Containers (B.27.001); Food and Drug Regulations, Government of Canada, Minister of Justice: Ottawa, ON, Canada, 2019. Available online: https://laws-lois.justice.gc.ca (accessed on 25 March 2020).

27. Erdoğdu, F.; Balaban, M.O.; Otwell, W.; Garrido, L. Cook-related yield loss for pacific white (Penaeus vannamei) shrimp previously treated with phosphates: Effects of shrimp size and internal temperature distribution. J. Food Eng. 2004, 64, 297-300. [CrossRef]

28. Janssen, R.H.; Lakemond, C.M.M.; Fogliano, V.; Renzone, G.; Scaloni, A.; Vincken, J.-P. Involvement of phenoloxidase in browning during grinding of Tenebrio molitor larvae. PLOS ONE 2017, 12, e0189685. [CrossRef] [PubMed]

29. Janssen, R.H.; Vincken, J.-P.; Arts, N.J.; Fogliano, V.; Janssen, R.H. Effect of endogenous phenoloxidase on protein solubility and digestibility after processing of Tenebrio molitor, Alphitobius diaperinus and Hermetia illucens. Food Res. Int. 2019, 121, 684-690. [CrossRef]

30. Janssen, R.H.; Canelli, G.; Sanders, M.G.; Bakx, E.J.; Lakemond, C.M.M.; Fogliano, V.; Vincken, J.-P. Iron-polyphenol complexes cause blackening upon grinding Hermetia illucens (black soldier fly) larvae. Sci. Rep. 2019, 9, 2967. [CrossRef]

31. David-Birman, T.; Raften, G.; Lesmes, U. Effects of thermal treatments on the colloidal properties, antioxidant capacity and in-vitro proteolytic degradation of cricket flour. Food Hydrocoll. 2018, 79, 48-54. [CrossRef]

32. Melis, R.; Braca, A.; Mulas, G.; Sanna, R.; Spada, S.; Serra, G.; Fadda, M.L.; Roggio, T.; Uzzau, S.; Anedda, R. Effect of freezing and drying processes on the molecular traits of edible yellow mealworm. Innov. Food Sci. Emerg. Technol. 2018, 48, 138-149. [CrossRef]

33. Kennedy, C.J. Freezing processed foods. In Managing Frozen Foods; Woodhead Publishing: Cambridge, UK, $2000 ;$ p. 304.

34. Barden, L.; Decker, E.A. Lipid Oxidation in Low-moisture Food: A Review. Crit. Rev. Food Sci. Nutr. 2013, 56, 2467-2482. [CrossRef]

35. Robles-Martinez, C.; Cervantes, E.; Ke, P.J. Recommended method for testing the objective rancidity development in fish based on TBARS formation. Can. Tech. Rep. Fish. Aquat. Sci. 1982, 1089, 1-27. 
36. Wazir, H.; Chay, S.Y.; Zarei, M.; Hussin, F.S.; Mustapha, N.A.; Ibadullah, W.Z.W.; Saari, N. Effects of Storage Time and Temperature on Lipid Oxidation and Protein Co-Oxidation of Low-Moisture Shredded Meat Products. Antioxidants 2019, 8, 486. [CrossRef] [PubMed]

37. Soyer, A.; Özalp, B.; Dalmış, Ü.; Bilgin, V. Effects of freezing temperature and duration of frozen storage on lipid and protein oxidation in chicken meat. Food Chem. 2010, 120, 1025-1030. [CrossRef]

38. Tiencheu, B.; Womeni, H.M.; Linder, M.; Mbiapo, F.T.; Villeneuve, P.; Fanni, J.; Parmentier, M. Changes of lipids in insect (Rhynchophorus phoenicis) during cooking and storage. Eur. J. Lipid Sci. Technol. 2012, 115, 186-195. [CrossRef]

39. Lenaerts, S.; Van Der Borght, M.; Callens, A.; Van Campenhout, L. Suitability of microwave drying for mealworms (Tenebrio molitor) as alternative to freeze drying: Impact on nutritional quality and colour. Food Chem. 2018, 254, 129-136. [CrossRef]

(C) 2020 by the authors. Licensee MDPI, Basel, Switzerland. This article is an open access article distributed under the terms and conditions of the Creative Commons Attribution (CC BY) license (http://creativecommons.org/licenses/by/4.0/). 